\title{
Article \\ Combination of GC-MS Molecular Networking and Larvicidal Effect against Aedes aegypti for the Discovery of Bioactive Substances in Commercial Essential Oils
}

\author{
Alan Cesar Pilon ${ }^{1,+}{ }^{\circledR}$, Marcelo Del Grande ${ }^{1,+}$, Maíra R. S. Silvério ${ }^{1}$, Ricardo R. Silva ${ }^{1}$, Lorena C. Albernaz ${ }^{2}{ }^{\circledR}$, \\ Paulo Cézar Vieira ${ }^{1}$ (D) João Luis Callegari Lopes ${ }^{1}$, Laila S. Espindola ${ }^{2}$ and Norberto Peporine Lopes ${ }^{1, *(1)}$ \\ 1 Núcleo de Pesquisa em Produtos Naturais e Sintéticos (NPPNS), Departamento de Ciências Biomoleculares, \\ Faculdade de Ciências Farmacêuticas de Ribeirão Preto, Universidade de São Paulo—USP, \\ Ribeirão Preto 14040-903, Brazil; pilonac@gmail.com (A.C.P.); marcelo.grande@yahoo.com.br (M.D.G.); \\ mairarosato@gmail.com (M.R.S.S.); rsilvabioinfo@gmail.com (R.R.S.); paulocezarv@gmail.com (P.C.V.); \\ joaoluis@usp.br (J.L.C.L.) \\ 2 Laboratório de Farmacognosia, Campus Universitário Darcy Ribeiro, Universidade de Brasília, \\ Brasília 70910-900, Brazil; lorena.albernaz@gmail.com (L.C.A.); darvenne@gmail.com (L.S.E.) \\ * Correspondence: npelopes@fffrp.usp.br \\ + These authors contributed equally to this work.
}

Citation: Pilon, A.C.; Del Grande, M.; Silvério, M.R.S.; Silva, R.R.; Albernaz, L.C.; Vieira, P.C.; Lopes, J.L.C.;

Espindola, L.S.; Lopes, N.P. Combination of GC-MS Molecular Networking and Larvicidal Effect against Aedes aegypti for the Discovery of Bioactive Substances in Commercial Essential Oils. Molecules 2022, 27, 1588. https://doi.org/ $10.3390 /$ molecules 27051588

Academic Editor: Josphat Matasyoh

Received: 25 January 2022

Accepted: 24 February 2022

Published: 28 February 2022

Publisher's Note: MDPI stays neutral with regard to jurisdictional claims in published maps and institutional affiliations.

Copyright: (C) 2022 by the authors. Licensee MDPI, Basel, Switzerland. This article is an open access article distributed under the terms and conditions of the Creative Commons Attribution (CC BY) license (https:// creativecommons.org/licenses/by/ $4.0 /)$.

\begin{abstract}
Dengue is a neglected disease, present mainly in tropical countries, with more than 5.2 million cases reported in 2019. Vector control remains the most effective protective measure against dengue and other arboviruses. Synthetic insecticides based on organophosphates, pyrethroids, carbamates, neonicotinoids and oxadiazines are unattractive due to their high degree of toxicity to humans, animals and the environment. Conversely, natural-product-based larvicides/insecticides, such as essential oils, present high efficiency, low environmental toxicity and can be easily scaled up for industrial processes. However, essential oils are highly complex and require modern analytical and computational approaches to streamline the identification of bioactive substances. This study combined the GC-MS spectral similarity network approach with larvicidal assays as a new strategy for the discovery of potential bioactive substances in complex biological samples, enabling the systematic and simultaneous annotation of substances in 20 essential oils through $\mathrm{LC}_{50}$ larvicidal assays. This strategy allowed rapid intuitive discovery of distribution patterns between families and metabolic classes in clusters, and the prediction of larvicidal properties of acyclic monoterpene derivatives, including citral, neral, citronellal and citronellol, and their acetate forms $\left(\mathrm{LC}_{50}<50 \mu \mathrm{g} / \mathrm{mL}\right)$.
\end{abstract}

Keywords: dengue; essential oils; large datasets; molecular networking; larvicidal activity

\section{Introduction}

Dengue is a viral infection transmitted mainly by the female Aedes aegypti mosquito. This disease mainly affects tropical regions, depending on the rain precipitation rate, temperature, humidity and urbanization process [1-7]. The number of cases has increased almost 8-fold over the last 2 decades (from 505,430 in 2000 to 2.4 million in 2010; 4.2 million in 2019), leading to the death of more than 4000 people in 2015. Regions of Latin America, East Asia and the Western Pacific account for over $70 \%$ of the cases. In Brazil, more than 1.5 million cases (more than 1000 deaths) were recorded in 2016 alone $[1,7,8]$.

The WHO indicates that combatting the transmitting mosquito is the most efficient strategy to control and prevent dengue [9]. However, there are still no specific insecticides or repellents (natural or synthetic) to exclusively combat the Ae. Aegypti mosquito. Consequently, insecticides and repellents can cause disturbances and/or the mortality of important insects, such as bees and ants, resulting in the degradation of important ecosystem services, including the pollination of crops [9]. Thus, nontoxic and specific repellent agents or larvicides against Ae. aegypti are urgently required to both reduce the number of 
arboviral disease cases (dengue, Zika and chikungunya) and protect the ecological roles of insects.

In order to address the aforementioned concerns, the Brazilian National Dengue Control Program has promoted the replacement of these synthetic compounds with substances that are less harmful to the environment. Organophosphates (malathion, fenitrothion and temephos) initially replaced organochlorines, which were in turn replaced by pyrethroids (cypermethrin and deltamethrin). However, these compounds still present some toxicity and continue to endanger populations of pollinating insects, animals and the environment [8].

Since the last century, efforts have been made to source products of natural origin with activity against Ae. Aegypti, such as pyrethrum and neem oil; although, no commercial products have been approved/authorized by Brazilian regulatory bodies to date. The literature reports the potential of various natural insecticides, especially those of microbial and plant origin $[10,11]$. The arms race between insects, plants and microorganisms constitutes a large part of the known metabolic arsenal, the so-called secondary metabolites or "special" metabolites. Today, it is estimated that more than 100,000 plant-derived metabolites may have some activity against insects and microorganisms [12].

Among the advantages of natural pesticides/larvicides, we can highlight their environmental safety, biodegradation and multiple mechanisms of action through synergistic effects. However, while the biodegradation of botanical active ingredients may sound positive, it actually represents a double-edged sword. There is generally greater compatibility between the released biocontrol agents and other natural enemies and greater safety for bees and other pollinators $[8,13]$. However, the lack of persistence of these bio-insecticides in crops under real field conditions brings some disadvantages. Most botanical insecticides are highly susceptible to photodegradation (e.g., pyrethrins), abiotic oxidation (azadiractins) or volatilization loss (essential oil terpenoids) when applied outside a controlled environment (e.g., indoors), requiring their reapplication when used on monocultures. Despite this limitation, certain botanical insecticides have proven records dating back 2-3 decades, confirming their effectiveness in the field [14,15]. Between 2007 and 2016, the state of California used azadirachtin, chenopodium and natural pyrethrins as the main botanical assets for pest control. However, recent formulation developments present opportunities to dramatically improve the field performance of botanical insecticides in terms of their efficacy and persistence [16,17].

The search for larvicidal agents present in essential oils (EO), plants or natural extracts requires increasingly modern analytical and computational tools, since these natural products are composed of dozens and even hundreds of compounds [18-21]. Recently, innovative methods based on LC-MS ${ }^{n}$ have been applied for untargeted metabolomic analysis to accelerate the structural annotation of compounds [12,22-25]. The increased sharing of experimental MS/MS data and the growing number of spectral databases, such as NIST, METLIN, MassBank, MASST, NuBBE ${ }_{\mathrm{DB}}$, Sumner/Bruker and ReSpect, have promoted the development of several bioinformatics approaches that help in the interpretation of large MS/MS datasets [26-33].

One of these approaches is the concept of spectral similarity networking (so-called molecular networks-MN) which is based on the organization and visualization of MS/MS data via spectral similarity (homologous fragments) [24,34-39]. Structurally related compounds often share similar MS/MS spectra. The MN groups these compounds (nodes) according to the degree of spectral similarity as a network in a knowledge graph format, thus allowing visual exploration of identical/analogous molecules and accelerating the identification of subgroups or characteristics of a given group of molecules. Chemical annotation via molecular networking arises from the combination of direct spectral correspondence between MS/MS spectra and compound libraries (MS/MS data) and through the relationship of molecular network masses (differences) between closely related structures (degree of spectral similarity). A mass difference of 15 Da between nodes with a high degree of similarity may suggest a $\mathrm{CH}_{3}$ group for the same class of compound, while 
differences of 162, 146 or 132 Da may correspond to homologues glycosylated with hexose, deoxyhexose or pentose [36,39-42].

In this study, we propose a strategy combining the spectral similarity networking (molecular networking) approach with larvicidal activity tests against Ae. aegypti to analyze commercial essential oils with the aim of discovering potential bioactive metabolic classes. The GC-MS retention time and fragmentation, chemotaxonomy and larvicidal activity against $A$ e. aegypti ( $\mathrm{LC}_{50}$ values) of essential oils were organized, grouped and evaluated by molecular networking. Figure 1 shows a graphical representation of the strategy.

\section{Stralegy combining Spedial Similarily Nelwork and biological assaty}

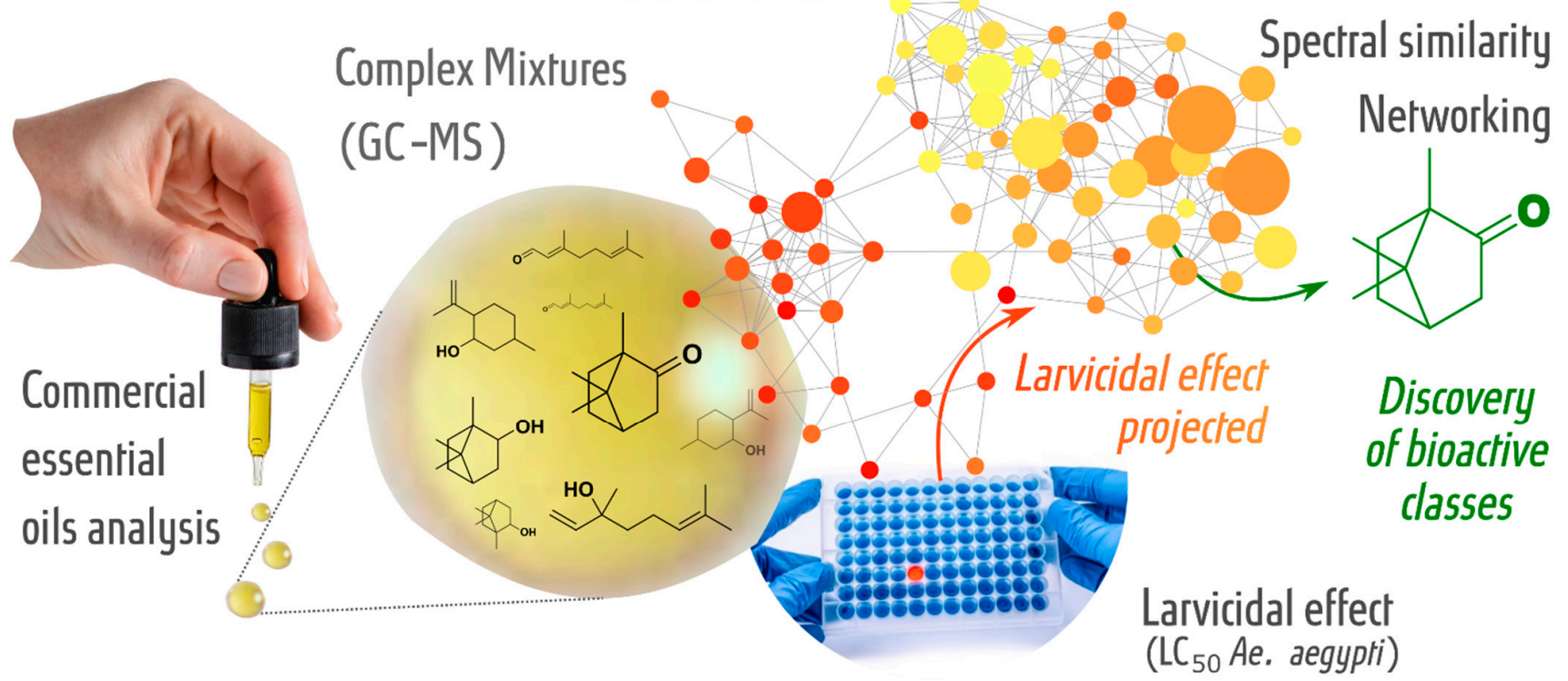

Figure 1. Strategy for the discovery of potential bioactive classes: spectral similarity networking (GC-MS data) combined with biological assays (larvicidal assay- $-\mathrm{LC}_{50}$ values).

\section{Results}

Essential oils from 20 plant species (from 9 families) with insecticidal properties were analyzed by an untargeted profiling method using GC-EI/MS (Supplementary Materials) and tested against Ae. aegypti larvae (third instar, L3), evaluating their mortality rate at $24 \mathrm{~h}$ and $48 \mathrm{~h}$, Table 1. According to Dermaque et al. [43], an initial screening strategy to preselect an extract active against Ae. aegypti larvae involves testing at a single concentration, standardized at $250 \mathrm{ppm}$.

Species of the genera Lavandula, Cymbopogon, Rosmarinus, Citrus, Perlagonium and Amyris demonstrated larvicidal activity, while the other essential oils presented little or no activity. Among them, it is noted that the essential oils of the genus Eucalyptus, as well as the species of Cymbopogon and Litsea, had highly active $\mathrm{LC}_{50}$ values of: Eucalyptus citriodora $(23.3 \mu \mathrm{g} / \mathrm{mL})$, Eucalyptus staigeriana $(43.1 \mu \mathrm{g} / \mathrm{mL})$, Cymbopogon nardus $(31.3 \mu \mathrm{g} / \mathrm{mL})$, Cymbopogon flexuosus $(41.7 \mu \mathrm{g} / \mathrm{mL})$ and Litsea cubeba $(32.7 \mu \mathrm{g} / \mathrm{mL})$.

In order to annotate and streamline the process of discovering bioactive classes in essential oils, we applied the molecular network approach with retention time and fragmentation data from the GC-MS/MS experiments and metadata, such as taxonomy and $\mathrm{LC}_{50}$ values calculated in the Ae. aegypti larvicidal tests.

\section{Molecular Networking}

The molecular network of 20 essential oils resulted in 82 nodes (with qualitative, quantitative and metadata for each compound), connected by 258 edges and grouped into a large cluster with 76 nodes and 6 lone pairs, as shown in Figure 2. One of the advantages 
of $\mathrm{MN}$ is the ability to create filters for nodes and edges in order to recognize patterns in the dataset. In this sense, different colors were attributed to nodes considering the retention time of the compounds present in the GC-MS profiles (red-longer RT; yellow-shorter RT) and to the relative abundance of ions represented by the node sizes (Figure 2).

Table 1. Commercial essential oil larvicidal assay (mortality rate at $24 \mathrm{~h}$ and $48 \mathrm{~h}$ ) results and corresponding $\mathrm{LC}_{50}$ values determined against Ae. aegypti.

\begin{tabular}{|c|c|c|c|c|c|c|}
\hline Sample & Species (Family) & Batch & $\begin{array}{c}\text { Major Compound } \\
(\%)\end{array}$ & $\begin{array}{c}\text { Mortality } \\
250 \mu \mathrm{g} / \mathrm{mL} \\
(\%, 24 \mathrm{~h})\end{array}$ & $\begin{array}{c}\text { Mortality } \\
250 \mu \mathrm{g} / \mathrm{mL} \\
(\%, 48 \mathrm{~h})\end{array}$ & $\begin{array}{c}\mathrm{LC}_{50} \\
(\mu \mathrm{g} / \mathrm{mL}) \\
(24 \mathrm{~h})\end{array}$ \\
\hline 01 & $\begin{array}{l}\text { Juniperus communis } \\
\text { (Cupressaceae) }\end{array}$ & 180113 & $\alpha$-pinene (38.9) & 75 & 82.5 & 135.2 \\
\hline 02 & $\begin{array}{l}\text { Origanum majorana } \\
\text { (Lamiacae) }\end{array}$ & 180319 & terpinen-4-ol (25.2) & 82.5 & 80 & 121.3 \\
\hline 03 & $\begin{array}{c}\text { Cymbopogon martini } \\
\text { (Poaceae) }\end{array}$ & 180227 & geraniol (80.6) & 87.5 & 92.5 & 73.88 \\
\hline 07 & $\begin{array}{l}\text { Boswellia carteri } \\
\text { (Burseraceae) }\end{array}$ & 180217 & $\alpha$-pinene (43.8) & 42.5 & 75 & 129.8 \\
\hline 08 & $\begin{array}{l}\text { Mentha piperita } \\
\text { (Lamiaceae) }\end{array}$ & 180418 & menthol (45.7) & 100 & 100 & 95.29 \\
\hline 09 & $\begin{array}{l}\text { Citrus aurantium var. } \\
\text { amara (Rutaceae) }\end{array}$ & 180206 & D-limonene (96.9) & 42.5 & 60 & 177.1 \\
\hline 10 & $\begin{array}{c}\text { Eucalyptus citriodora } \\
\text { (Myrtaceae) }\end{array}$ & 180307 & citronelal (74.4) & 100 & 100 & 23.26 \\
\hline 11 & $\begin{array}{c}\text { Eucalyptus globulus } \\
\text { (Myrtaceae) }\end{array}$ & 180205 & eucalyptol (89.9) & 87.5 & 97.5 & 276.6 \\
\hline 14 & $\begin{array}{l}\text { Lavandula angustifolia } \\
\text { (Lamiaceae) }\end{array}$ & 180408 & linalyl acetate (63.0) & 100 & 100 & 85.88 \\
\hline 16 & $\begin{array}{l}\text { Lavandula hybrida } \\
\text { (Lamiaceae) }\end{array}$ & 180403 & linalool (36.2) & 70 & 70 & 109 \\
\hline 18 & $\begin{array}{c}\text { Cymbopogon flexuosus } \\
\text { (Poaceae) }\end{array}$ & 180326 & citral (50.6) & 100 & 100 & 41.66 \\
\hline 19 & $\begin{array}{c}\text { Cymbopogon nardus } \\
\text { (Poaceae) }\end{array}$ & 180306 & citronelal (45.9) & 100 & 100 & 31.25 \\
\hline 20 & $\begin{array}{l}\text { Cedrus atlantica } \\
\text { (Pinaceae) }\end{array}$ & 180226 & $\beta$-himachalene & 60 & 65 & 269.1 \\
\hline 21 & $\begin{array}{l}\text { Rosmarinus officinalis } \\
\text { (Lamiaceae) }\end{array}$ & 180415 & camphor (23.6) & 90 & 90 & 80.33 \\
\hline 23 & $\begin{array}{c}\text { Citrus aurantium subsp. } \\
\text { Bergamia (Rutaceae) }\end{array}$ & 180402 & D-limonene (38.2) & 100 & 100 & 99.57 \\
\hline 24 & $\begin{array}{c}\text { Pelargonium graveolens } \\
\text { (Geraniaceae) }\end{array}$ & 171234 & citronellol (35.3) & 100 & 100 & 78.32 \\
\hline 27 & $\begin{array}{l}\text { Litsea cubeba } \\
\text { (Lauraceae) }\end{array}$ & 180412 & citral (47.7) & 100 & 100 & 32.74 \\
\hline 31 & $\begin{array}{c}\text { Salvia sclareia } \\
\text { (Lamiaceae) }\end{array}$ & 180405 & linalyl acetate (71.0) & 60 & 75 & 120 \\
\hline 33 & $\begin{array}{c}\text { Amyris balsamifera } \\
\text { (Rutaceae) }\end{array}$ & 180214 & valencene (21.5) & 100 & 100 & 99.51 \\
\hline 34 & $\begin{array}{c}\text { Eucalyptus staigeriana } \\
\text { (Myrtaceae) }\end{array}$ & 180207 & D-limonene (29.2) & 100 & 100 & 43.13 \\
\hline N.C. ${ }^{1}$ & $<1 \%$ DMSO & - & & - & - & - \\
\hline P. C. ${ }^{2}$ & $\begin{array}{l}\text { Temephos }(100 \% \\
\text { mortality) }\end{array}$ & - & - & 0.35 & 0.35 & 0.019 \\
\hline
\end{tabular}

The distribution of colors in the cluster regions indicated that different classes of metabolites must be grouped differently. In addition, most of the compounds (nodes) were eluted between 7 and $20 \mathrm{~min}$, which may denote certain metabolic classes and, consequently, assist in the annotation process. 

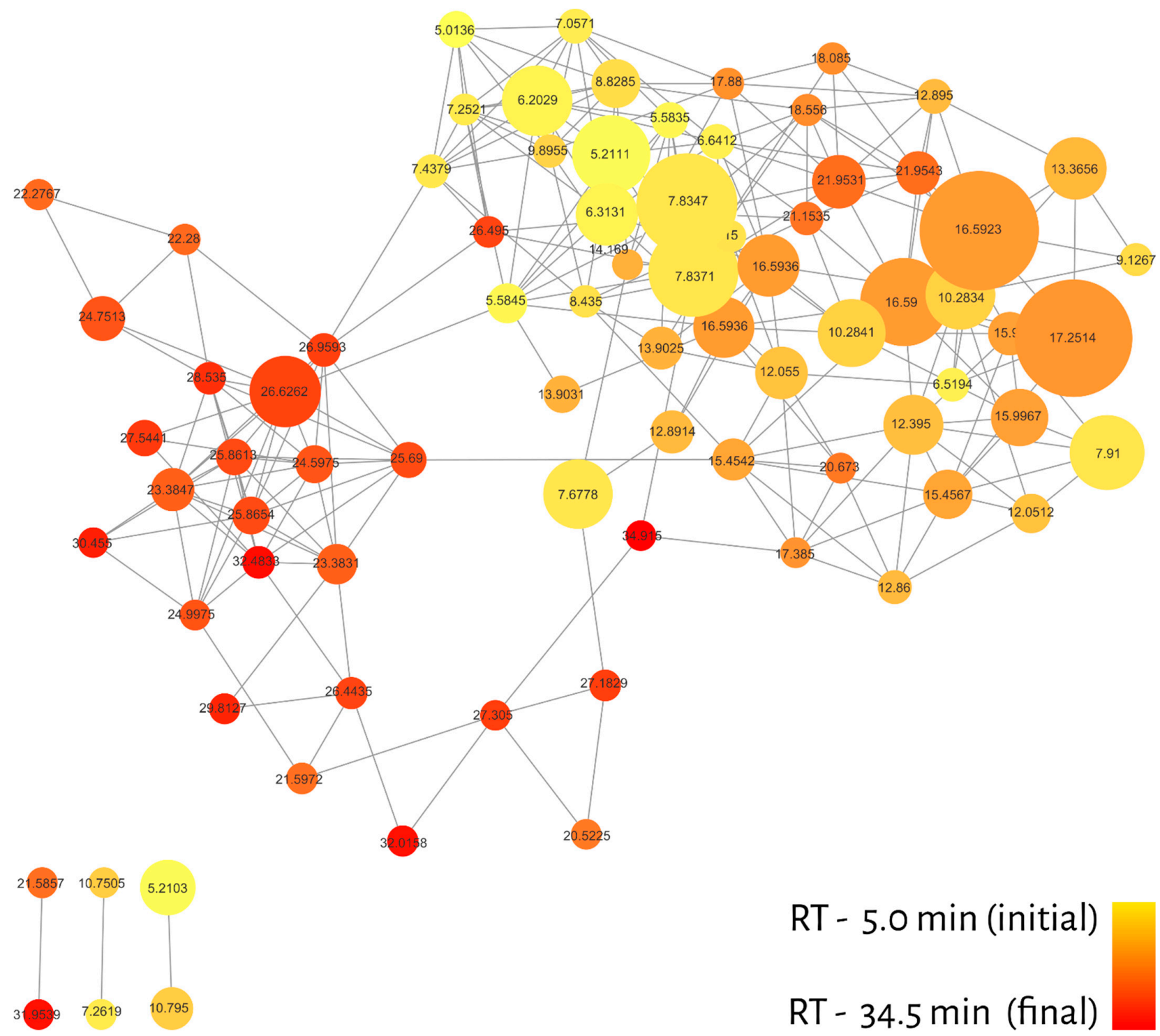

\section{RT - 5.0 min (initial) \\ $\mathrm{RT}-34.5 \mathrm{~min}$ (final)}

Figure 2. Molecular network filtered by retention time (RT). The color gradient is represented by yellow (initial) and red (end), while the node size represents the relative abundance of ions.

Another aspect is to evaluate the correlation of these compounds between families and their chemotaxonomic characteristics. It is also possible to make an indirect association between the chemotypes and the larvicidal potential of the cluster regions.

Figure 3 shows the MN using the compound distribution filter (relative abundance of ions) among the families using a color gradient in the nodes. Yellow represents little or no abundance, while blue represents a high abundance of ions. The Burseraceae and Cupressaceae families presented a strong correlation with most of their compounds (nodes) located in the region with the lowest retention times. Geraniaceae and Lamiaceae displayed a wide distribution of their compounds in the MN, while metabolites in Lauraceae, Myrtaceae, Poaceae and Rutaceae were observed between 7 and $20 \mathrm{~min}$. Pinaceae concentrated its compounds in longer retention times.

Larvicidal activity against $A$ e. aegypti was used as a filter for the third step of evaluating the molecular network of commercial essential oils. The $\mathrm{LC}_{50}$ values (Table 1 ) from essential oils were used in two different ways to calculate the individual larvicidal activity for each node (substance). First, we calculated the average of the $\mathrm{LC}_{50}$ values for each node (one substance may be present in different EO), Figure 4A. Alternatively, we calculated the relative average considering ion abundance (present differently in each EO) for each 
node, Figure 4B. In both molecular networks (Figure 4A,B), we colored the maximum and minimum calculated $\mathrm{LC}_{50}$ values in four equidistant categories. The pink color represents the most active nodes, followed by blue, green and yellow. Although the ranges were different between the different averages, the color pattern was similar.

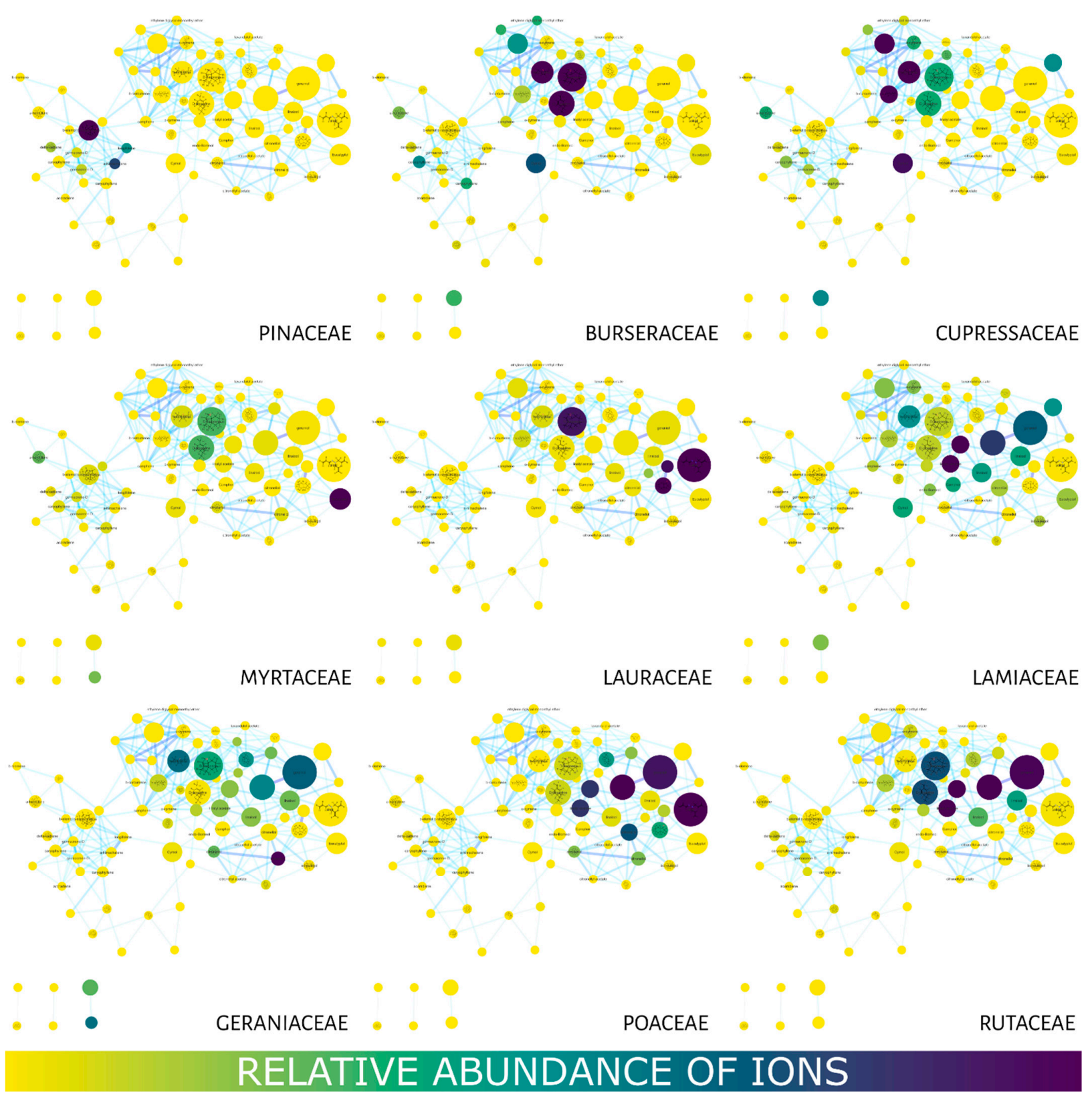

Figure 3. Molecular networks filtered for the relative abundance of ions present in the studied families. The color gradient represents ion (compound) abundance in the essential oils (family). Yellow-low or no abundance; blue- - high abundance. The node size also represents the total relative abundance of ions.

As a result, it was possible to observe three regions of molecular network with different larvicidal potentials. It is important to emphasize that these regions are projections of bioactivity, but may be used as a guide for regions/compounds to be explored and studied. In this case, for both averages (molecular networks) the lower right side of the cluster, colored in pink and blue, suggests a region with higher larvicidal potential. In Figure 4B, there is also a pink diagonal projecting this potential. 

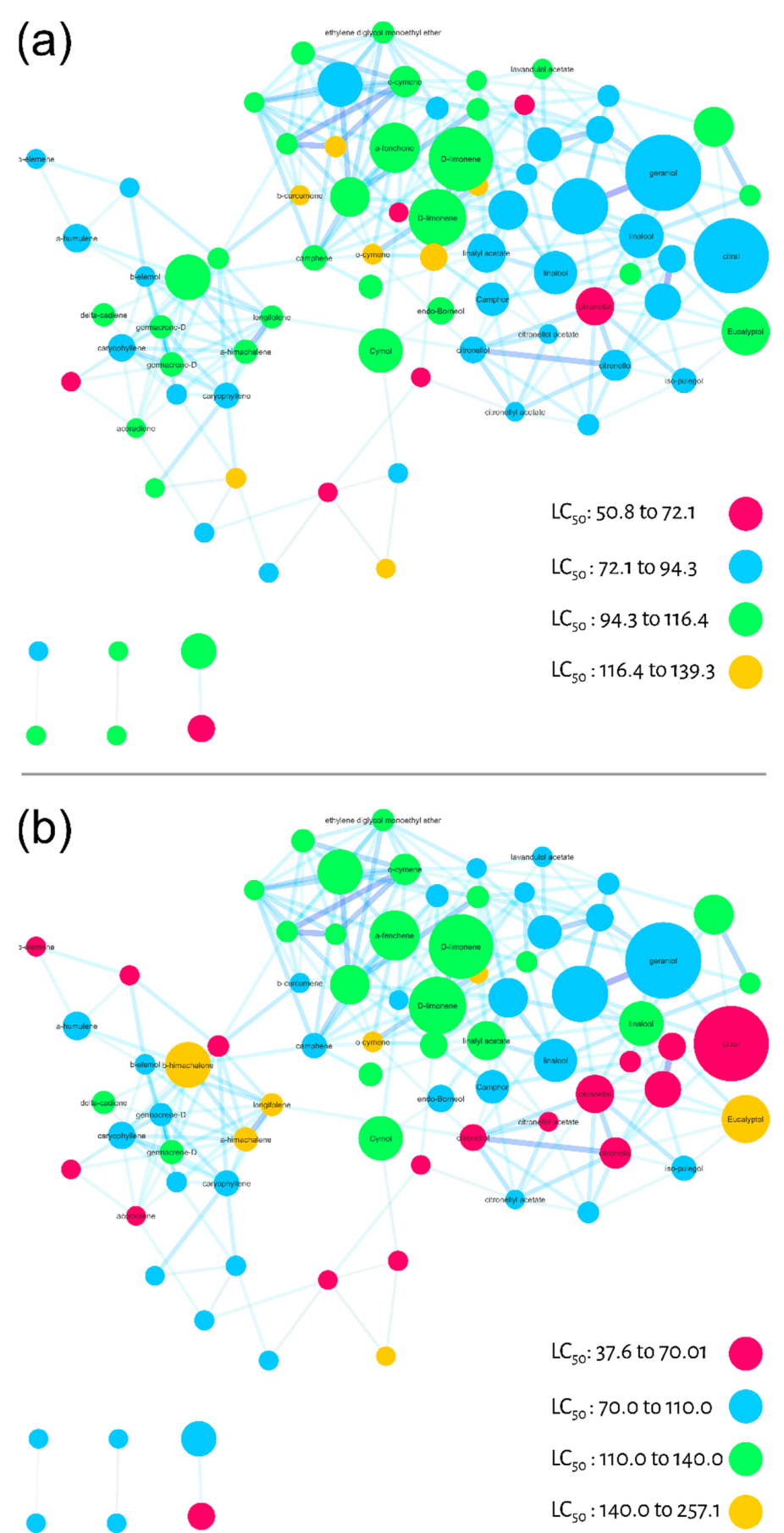

Figure 4. Molecular networks filtered by the calculated $\mathrm{LC}_{50}$ values ( $24 \mathrm{~h}$ larvae mortality) of the essential oils for each node. (a) Average of $\mathrm{LC}_{50}$ values calculated qualitatively (not considering the relative abundance of ions). (b) Relative average of $\mathrm{LC}_{50}$ values considering the relative abundance of ions.

The fourth filter of this molecular networking was to annotate the nodes. We used the GNPS library combined with our in-house NIST database and gas-phase fragmentation data. The annotated compounds were then classified hierarchically according to the NPClassifier ontology [44], as shown in Figure 5.

Figure 5 represents the filtered molecular network for compound annotation. The ellipse represents the level of the superclass (terpenes), while the colors represent the distribution of classes into monoterpenes (orange) and sesquiterpenes (purple). In the lower part of Figure 5, it is possible to observe the group of expanded monoterpenes and 
sesquiterpenes. Eight subclasses were found for monoterpenes: acyclic (orange), camphane (green), fatty alcohols (light blue), menthane (blue), monocyclic (purple), pinane (pink) and thujan (red), while six subclasses were classified as sesquiterpenes: cadinan (yellow), caryophyllane (green), elemane (light blue), germacrane (blue), himachalane (dark blue) and longifolene (pink) alcohols.

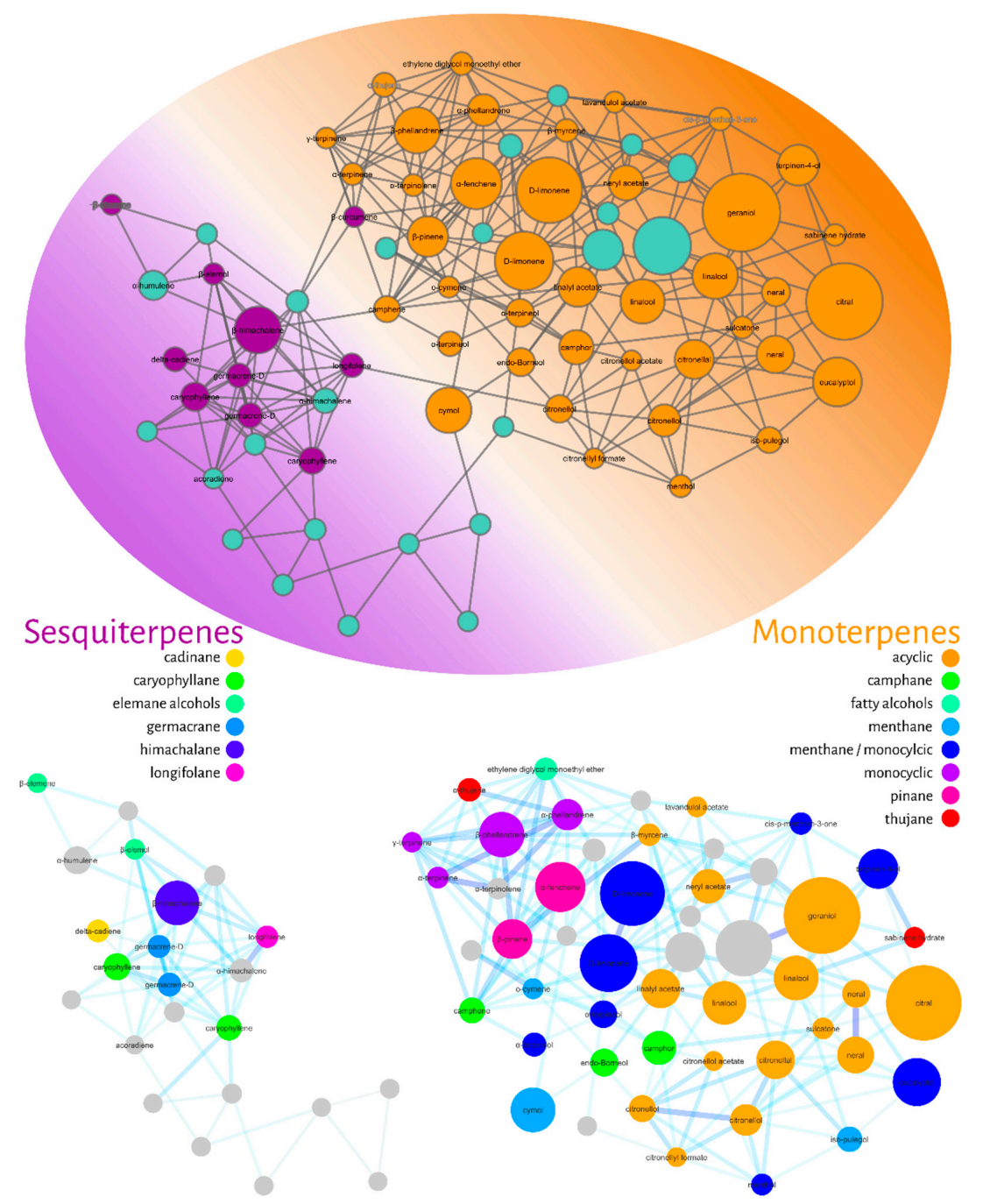

Figure 5. Molecular network filtered for compound annotation (nodes) using the GNPS library and an in-house NIST database. The annotated compounds were classified using the NP classifier ontology. The colors of the ellipse represent the annotated monoterpenes (orange) and sesquiterpenes (purple). At the bottom, the groupings of mono- and sesquiterpenes with their respective subclasses are expanded.

The potential bioactive nodes were annotated and classified as acyclic (orange), camphane (green) and menthane/monocyclic monoterpenes (dark blue). Specifically, the compounds with the lower $\mathrm{LC}_{50}$ values were annotated as citral (polyunsaturated and aldehyde as a functional group (FG)), neral (FG-aldehyde), citronellal (monoterpene-unsaturated and FG-aldehyde), citronellol (unsaturated and FG-alcohol), citronellol acetate (unsaturated and FG-acetate), isopulegol (unsaturated, monocyclic and FG-alcohol), linalool (poly-unsaturated and FG-alcohol), camphor (menthane and FG-ketone), and endo-borneol (menthane and FG-ketone).

Table 2 shows the list of annotated compounds, retention time ( $\mathrm{min})$, precursor ion values $(m / z)$, samples and relative $\mathrm{LC}_{50}$ values. 
Table 2. List of annotated compounds including the retention time (min), precursor ion values $(m / z)$, samples and relative $\mathrm{LC}_{50}$ values.

\begin{tabular}{|c|c|c|c|c|}
\hline$\underset{(\min )}{\mathrm{RT}}$ & Compound & $m / z^{*}$ & Samples & $\begin{array}{l}\text { Relative } \\
\text { LC }_{50}^{* *} \\
(\mu \mathrm{g} / \mathrm{mL})\end{array}$ \\
\hline 5.01 & thujene & 93.1 & $1,2,9,10,11,16,18,19,23,24,31$ & 125.6 \\
\hline 5.21 & pinene & 91.1 & $1,2,7,8,9,10,11,14,16,18,19,21,23,24,27,31$ & 105.9 \\
\hline 5.21 & fenchene & 93.1 & $1,2,7,8,9,10,11,14,16,18,19,20,21,23,24,27,31,33$ & 123.2 \\
\hline 5.58 & camphene & 93.1 & $1,2,9,10,14,16,18,19,23,27,31$ & 84.1 \\
\hline 6.20 & phellandrene & 93.1 & $1,2,7,9,10,11,18,20,23,24,27,31$ & 128.5 \\
\hline 6.31 & pinene & 93.1 & $1,2,8,9,10,11,14,18,23,24,27,31,33$ & 116.0 \\
\hline 6.52 & sulcatone & 43.0 & $1,2,3,7,8,9,10,11,14,16,18,19,20,24,27,31,33$ & 55.1 \\
\hline 6.64 & myrcene & 77.0 & $1,2,3,9,10,11,14,18,19,23,24,31,33$ & 130.2 \\
\hline 7.06 & ethylene diglycol monoethyl ether & 93.1 & $1,2,9,10,11,14,18,19,23,24,27,31$ & 127.5 \\
\hline 7.25 & terpinene & 93.1 & $1,9,10,11,16,18,23$ & 126.5 \\
\hline 7.44 & terpinene & 136.1 & $1,2,9,10,23,24,27$ & 120.3 \\
\hline 7.68 & cymol & 119.1 & $1,2,3,9,10,11,14,16,18,19,20,23,24,27,31,33$ & 124.7 \\
\hline 7.83 & D-limonene & 68.1 & $1,2,3,8,9,10,11,14,16,18,19,20,23,24,27,31,33$ & 119.6 \\
\hline 7.91 & eucalyptol & 43.0 & $1,2,3,7,8,9,10,11,14,16,18,19,20,23,24,27,31$ & 229.6 \\
\hline 8.44 & cymene & 93.1 & $1,2,3,9,10,11,14,16,18,19,24,33$ & 150.1 \\
\hline 8.83 & phellandrene & 93.1 & $1,2,7,9,10,11,14,18,20,23,24,27,31$ & 120.3 \\
\hline 9.13 & sabinene hydrate & 71.1 & $2,10,18$ & 120.9 \\
\hline 9.90 & terpinolene & 93.1 & $1,2,9,10,11,14,18,20,23,24,27$ & 124.0 \\
\hline 10.28 & linalool & 71.1 & $1,2,3,7,9,10,11,16,18,19,20,23,24,27,31,33$ & 105.9 \\
\hline 12.05 & iso-pulegol & 41.0 & $9,10,18,19,20,23,27,31$ & 86.5 \\
\hline 12.06 & camphor & 95.1 & $9,10,16,18,20,23,27$ & 86.8 \\
\hline 12.40 & citronellal & 41.1 & $2,10,19,20,27,31$ & 51.9 \\
\hline 12.86 & menthol & 112.1 & $10,18,27$ & 93.0 \\
\hline 12.89 & endo-Borneol & 95.1 & $1,2,9,10,16,18,19,21,23,27,33$ & 94.8 \\
\hline 12.90 & cis- $p$-menthan-3-one & 69.1 & $10,16,18,23$ & 96.7 \\
\hline 13.37 & terpinen-4-ol & 71.1 & $1,2,7,9,10,11,16,18,31$ & 121.5 \\
\hline 13.90 & terpineol & 93.1 & $1,2,9,10,11,14,16,18,19,20,21,23,24,27,31,33$ & 125.2 \\
\hline 15.45 & citronellol & 69.1 & $1,2,3,7,11,18,19,20,24,27,31,33$ & 48.3 \\
\hline 15.98 & neral & 41.1 & $3,10,11,18,19,20,24,27,31$ & 39.6 \\
\hline 16.59 & geraniol & 69.1 & $2,3,7,10,11,16,18,19,20,24,27,31,33$ & 97.2 \\
\hline 16.59 & linalyl acetate & 93.1 & $2,3,7,10,11,16,18,19,20,23,24,27,31,33$ & 112.0 \\
\hline 17.25 & citral & 69.1 & $3,7,10,11,16,19,20,24,27,31,33$ & 37.6 \\
\hline 17.39 & citronellyl formate & 109.1 & $10,16,24,27$ & 84.5 \\
\hline 17.88 & unknown & 95.1 & $1,2,9,16,18,23$ & 92.9 \\
\hline 18.09 & lavandulol acetate & 69.1 & 16,18 & 104.5 \\
\hline 18.56 & unknown & 69.1 & $3,19,20,27,33$ & 78.2 \\
\hline 20.52 & unknown & 119.1 & $1,7,9,21$ & 144.5 \\
\hline 20.67 & citronellol acetate & 81.1 & $1,20,27,31,34$ & 40.6 \\
\hline 21.15 & unknown & 69.1 & $2,3,7,11,16,18,19,24,27,33$ & 114.3 \\
\hline 21.59 & unknown & 41.0 & $1,7,9,19,24,31,33$ & 76.4 \\
\hline 21.60 & unknown & 119.1 & $1,3,7,9,10,19,27,31,33$ & 92.6 \\
\hline 21.95 & neryl acetate & 69.1 & $1,2,3,7,11,16,18,19,20,24,27,31,33$ & 92.3 \\
\hline 22.28 & elemene & 81.1 & $1,7,8,9,10,20$ & 58.7 \\
\hline 23.38 & caryophyllene & 79.1 & $1,2,3,7,8,9,10,11,16,18,19,23,27,31,33,34$ & 97.8 \\
\hline 24.60 & himachalene & 93.1 & $7,8,21,34$ & 247.8 \\
\hline 24.75 & humulene & 93.1 & $1,2,3,7,8,9,10,11,18,19,20,23,27,33,34$ & 79.1 \\
\hline 25.00 & acoradiene & 93.1 & $1,8,9,34$ & 66.1 \\
\hline 25.69 & longifolene & 93.1 & $1,7,8,9,20,21,27,34$ & 221.5 \\
\hline 25.86 & germacrene & 91.1 & $1,7,8,9,10,18,19,20,21,27,33,34$ & 93.2 \\
\hline 26.44 & unknown & 91.1 & $1,2,7,8,9,10,11,21,27,34$ & 100.9 \\
\hline 26.50 & curcumene & 121.1 & $1,2,7,9,10,11,21,33,34$ & 98.2 \\
\hline 26.63 & himachalene & 119.1 & $1,7,8,9,16,20,21,34$ & 257.1 \\
\hline 26.96 & unknown & 69.1 & $7,8,9,18,21,24,34$ & 55.1 \\
\hline 27.18 & unknown & 161.1 & $1,7,8,9,18,19,20$ & 69.0 \\
\hline 27.31 & unknown & 122.1 & $7,8,34$ & 65.9 \\
\hline 27.54 & cadiene & 119.1 & $1,7,8,9,10,18,19,20,21,27,34$ & 128.1 \\
\hline 28.54 & elemol & 107.1 & $9,20,34$ & 91.4 \\
\hline 29.81 & unknown & 91.1 & $1,2,3,8,9,16,18,19,21,31,33$ & 100.1 \\
\hline 30.46 & unknown & 95.1 & $7,27,34$ & 38.6 \\
\hline 31.95 & unknown & 91.1 & $1,2,7,8,9,18,20,21,34$ & 103.8 \\
\hline 32.02 & unknown & 161.1 & $1,7,9,18,20,34$ & 89.1 \\
\hline 32.48 & unknown & 95.1 & $1,7,8,9,20,34$ & 83.9 \\
\hline 34.92 & unknown & 69.1 & $3,7,34$ & 60.9 \\
\hline
\end{tabular}


To verify the predictive potential of the strategy to discover larvicides in essential oils, we tested some of the monoterpenes indicated by $\mathrm{MN}$ against Ae. aegypti larvae and calculated their $\mathrm{LC}_{50}$ values after $48 \mathrm{~h}$ exposure. Among the compounds tested were: $\alpha$-fenchene $(>100 \mu \mathrm{g} / \mathrm{mL})$; eucalyptol $(>100 \mu \mathrm{g} / \mathrm{mL})$; menthol $(>100 \mu \mathrm{g} / \mathrm{mL})$; citronellol (65.3 $\mu \mathrm{g} / \mathrm{mL})$; citronellal $(57.8 \mu \mathrm{g} / \mathrm{mL})$; cymol $(41.7 \mu \mathrm{g} / \mathrm{mL})$; citral $(40.1 \mu \mathrm{g} / \mathrm{mL})$; $\alpha$-phellandrene $(40.1 \mu \mathrm{g} / \mathrm{mL})$ and D-limonene $(27.1 \mu \mathrm{g} / \mathrm{mL})$.

Similarly, we projected the $\mathrm{LC}_{50}$ values of the tested compounds onto the molecular network to confirm the pharmacological patterns pointed out by MN, Figure 6. As a result, the diagonal indicated by $\mathrm{MN}$ including acyclic, monocyclic monoterpenes and menthanetype monoterpenes were active against Ae. aegypti larvae. In addition, some menthane-type monoterpene derivatives, such as D-limonene, were highly active.

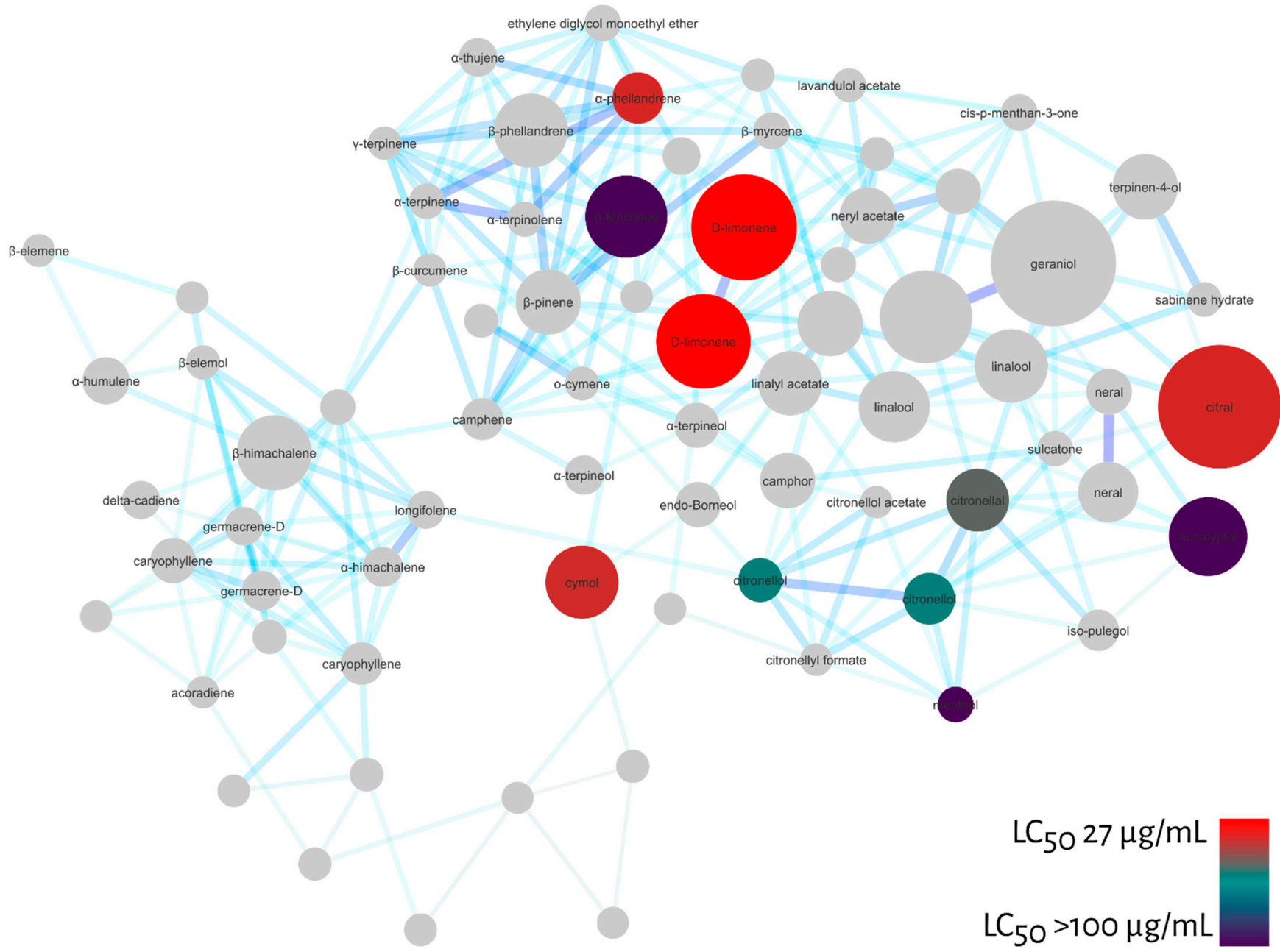

Figure 6. Molecular network filtered by $\mathrm{LC}_{50}$ values calculated for larval mortality at $48 \mathrm{~h}$ of Ae. aegypti for monoterpenes: $\alpha$-fenchene $(>100 \mu \mathrm{g} / \mathrm{mL})$, eucalyptol $(>100 \mu \mathrm{g} / \mathrm{mL})$, menthol $(>100 \mu \mathrm{g} / \mathrm{mL})$, citronellol $(65.3 \mu \mathrm{g} / \mathrm{mL})$, citronellal $(57.8 \mu \mathrm{g} / \mathrm{mL})$, cymol $(41.7 \mu \mathrm{g} / \mathrm{mL})$, citral $(40.1 \mu \mathrm{g} / \mathrm{mL}), \alpha$-phelandrene $(40.1 \mu \mathrm{g} / \mathrm{mL})$, D-limonene $(27.1 \mu \mathrm{g} / \mathrm{mL})$. Red nodes represent high larvicidal activity and dark blue nodules represent $\mathrm{LC}_{50}$ values $>100 \mu \mathrm{g} / \mathrm{mL}$.

\section{Discussion}

Essential oils and their structural analogues have historically made an important contribution as repellents or insecticides against $A$ e. aegypti in different communities $[8,14,45,46]$. However, larvicide/insecticide products based on natural products (NP) are scarce in the industry, revealing some difficulties associated with applying traditional approaches in NP $[43,47,48]$. 
Typically, a traditional approach uses organic solvents to produce crude extracts (polar or non-polar) that are screened for pharmacological activities and then fractionated into dozens of portions for further iterative bioguided analyses. In each cycle, the active fractions are reassembled after verification with spectral experiments, which can range from simple UV light to more expensive NMR analyses. Thus, the cost of pinpointing the NP-based product by traditional methods is high when considering that hundreds of extracts need to be analyzed to find a hit molecule $[47,49]$.

This challenge has been partially addressed through the development of dereplication methods, which aim to prioritize the discovery of bioactive substances, still in the crude extract, avoiding the re-isolation of interferents or known compounds. Dereplication uses previously established data (spectroscopic data, pharmacological and physicochemical properties) present in databases, scientific literature and computational tools to compare samples and reference material and, therefore, annotate and to attribute some properties to substances still in extracts or fractions. Despite offering advantages over traditional methods, this strategy faces some obstacles, as follows: (1) the databases and literature are not comprehensive and standardized, rendering it difficult to discover non-ubiquitous compounds; (2) the comparison process is still univariate between the sample(s) and the reference material, making the whole process time-consuming; (3) the global relationships between samples and metabolites are little explored [18,25,50,51].

On the other hand, chemometrics and bioinformatics have faced these obstacles introducing a holistic view of how to manage data and especially how to extract relevant information from vast datasets. Some of the strategies employed in genomics and proteomics are gradually being introduced into NP science. One such strategy is the use of spectral similarity information (or any other molecular data) that can provide clues as to how the constituents of a sample are organized (classes, substituents and properties) [38,40,52-54].

This organization concept is already used in the GNPS platform generating spectral networks of MS/MS data. Therefore, not only can single samples be screened for similarity, but hundreds or even thousands of samples can be organized into a single network, the so-called molecular network. Thus, using a spectral similarity score (cosine score) we can organize families, classes, substituents from one or several samples at once and still discover distribution patterns of unknown metabolites [25,55-59].

However, several parameters need to be adjusted to extract relevant information from the MS/MS data. In LC-MS, MS/MS experiments are performed in data dependent analysis (DDA), which means that each ion is initially isolated from the others, fragmented and then analyzed (collected). In contrast, most GC-MS systems do not possess an ion isolation chamber and the separation of substances depends on chromatographic resolution, which is often insufficient to separate all of the metabolites. This results in the fragmentation of more than one substance at the same time, making it difficult to apply spectral comparison (similarity) tools between samples and the reference [53,60].

In this sense, our strategy largely overcomes these limitations, since the MS/MS spec-tral data from GC-MS are initially deconvoluted and aligned by the Mzmine 2 tool and then compared and organized by spectral similarity networking (molecular network GNPS). As shown in Figures 2-6, it is possible to clearly visualize how substances are distributed throughout the chromatographic analysis, showing potential metabolic classes with different fragmentation profiles. It was possible to group information at the family level and discover patterns among them. We noticed that some families share similar MS/MS profiles, some of which have similar pharmacological properties. This allows us to extract chemotaxonomic information and prioritize bioactive families [61].

The incorporation of metadata into the molecular network opens up new opportunities to discover unknown patterns in samples. The relative mean of $\mathrm{LC}_{50}$ values from larvicidal experiments in Ae. aegypti, in several samples, allowed us to estimate the pharmacological effect of individual compounds that were repeatedly present in the samples and also indicate the bioactive ones. This is an innovative strategy in terms of discovering bioactive compounds in crude extracts, particularly in GC-MS experiments. 
We annotated compounds quickly and easily using our in-house library combined with the molecular network. Using the unknown to known annotation principle, the compounds determined by the library were used in the network to evaluate the neighbors (similar) and their spectra, facilitating and speeding up the annotation. During this process we also noticed that pharmacological patterns were associated with some metabolic classes such as acyclic, monocyclic and methane monoterpenes. Furthermore, they rationally shared some characteristics such as the presence of oxygen in the form of an alcohol or carbonyl group (acetate, aldehyde or ketone), an unsaturation index between 1 and 3, and masses between 152 and $156 \mathrm{Da}$. This suggests that this strategy can be employed to indicate potentially promising chemical classes.

Finally, we tested the larvicidal activity of some of the isolated monoterpenes, revealing the bioactive potential of some of them. We therefore confirmed the potential of the strategy to not only predict the pharmacological activity of compounds in crude extracts and fractions, but also facilitate pattern recognition in samples and metabolites.

\section{Materials and Methods}

The essential oils were purchased from BioEssência ${ }^{\circledR}$, Jaú, Brazil, and analyzed by dissolving in ethyl acetate at a concentration of $5 \mu \mathrm{g} / \mathrm{mL}$. Table 1 details the percentages of the major compounds in each essential oil.

\subsection{Larvicidal Activity against Ae. aegypti}

Larvicidal tests were performed with the Ae. aegypti Rockefeller strain. Third instar larvae (L3) were obtained from infection-free colonies maintained in the insectary of the Laboratory of Pharmacognosy of the University of Brasília. Colony maintenance is in accordance with World Health Organization guidelines [62] Monthly monitoring of this strain, which is susceptible to insecticides, using dose-response curves performed in 12-well plates with $10 \mathrm{~L} 3$ larvae, with temephos as the positive control (concentrations ranging from 0.05 to $0.003125 \mu \mathrm{g} / \mathrm{mL}$ ).

We optimized the WHO larvicidal trial to perform rapid screening and subsequent scale-up without harm. Assays were performed as described by Silva et al., 2020 [63], using 12-well plates, with $3 \mathrm{~mL}$ of tap water, $10 \mathrm{~L} 3$ larvae and $50 \mu \mathrm{L}$ of sample diluted in DMSO. This test is rapid, uses a small sample and allows the screening of many essential oil samples for major compounds.

The samples were tested in quadruplicate using a negative control of $0.025 \%$ dimethyl sulfoxide in tap water at $\mathrm{pH} 7.75$, conductivity at $34.5 \mu \mathrm{S} / \mathrm{cm}$ and temephos as the positive control. This organophosphate is used as a positive control due to its efficiency against Ae. aegypti Rockefeller strain $\left(100 \%\right.$ mortality at $0.35 \mu \mathrm{g} / \mathrm{mL}$ after 24 and $48 \mathrm{~h}$ with $\mathrm{LC}_{50}$ of $0.019 \mu \mathrm{g} / \mathrm{mL}$ ), being used in private companies in Brazil as a pest control agent.

For initial screening, only the mortalities of essential oils at the final concentration of $250 \mu \mathrm{g} / \mathrm{mL}$ were determined, after $24 \mathrm{~h}$ and $48 \mathrm{~h}$. The $50 \%$ lethal concentration values $\left(\mathrm{LC}_{50} \mu \mathrm{g} / \mathrm{mL}\right.$ ) were estimated using the test concentrations $250,125,62.5$ and $31.25 \mu \mathrm{g} / \mathrm{mL}$ for the essential oils and 100, 50, 25, 12.5 and $6.25 \mu \mathrm{g} / \mathrm{mL}$ for pure compounds (GraphPad Prism 7.0 software, GraphPad, La Jolla, CA, USA). Larvae mortality was determined after a $24 \mathrm{~h}$ exposure treatment. For each bioassay, the temperature was maintained at $28 \pm 2{ }^{\circ} \mathrm{C}$ and $70 \pm 10 \% \mathrm{RH}$, with a $12 \mathrm{~h}$ photoperiod.

\subsection{GC-MS Analysis}

For the essential oil analysis, we used the analytical methodology described by Adams (2007) with adaptations. Analysis involved gas chromatography coupled with mass spectrometer detection (GCMS-QP2010) according to the following parameters: injector temperature, $250{ }^{\circ} \mathrm{C}$; column temperature, $60{ }^{\circ} \mathrm{C}$; heating ramp from 60 to $210^{\circ} \mathrm{C}$, at $3{ }^{\circ} \mathrm{C} / \mathrm{min}$, with a total time of $50 \mathrm{~min}$; chromatographic column, DB-5, $30 \mathrm{~m} \times 0.25 \mathrm{~mm}$ in diameter, $0.25 \mu \mathrm{m}$ in thickness; helium was used as the carrier gas, under $79.7 \mathrm{kPa}$ at $1.30 \mathrm{~mL} / \mathrm{min}$, with a linear velocity of $41.6 \mathrm{~cm} / \mathrm{s}$ and $1 \mu \mathrm{L}$ injection volume and a 1:60 split. 
The mass detector parameters were as follows: ion source temperature, $250{ }^{\circ} \mathrm{C}$; interface temperature, $260^{\circ} \mathrm{C}$; solvent cutoff at $3.0 \mathrm{~min}$; Scan mode, from 35 to $400 \mathrm{~m} / \mathrm{z}$; detector voltage, $0 \mathrm{kV}$.

\subsection{Molecular Networking}

GC-EI/MS data were initially processed using the GCsolution (Shimadzu-Tokyo, Japan). Mass spectrometry molecular networks were created using the GNPS platform (http:/ /gnps.ucsd.edu, accessed on 30 November 2021) [35,64]. As the mass data from the EI experiments did not present pre-selection of precursor ions (called acquisition format of DIA), a spectral deconvolution was necessary. To achieve this, GC-MS data were analyzed and processed using the MzMine 2 package according to the parameters shown in Table 3.

Table 3. Mzmine 2 parameters for the commercial essential oil MS data analysis.

\begin{tabular}{|c|c|c|c|}
\hline Feature & LVL 1 & LVL 2 & Value \\
\hline \multirow[t]{3}{*}{ Mass Detection } & Scans & & $3.5-50.0 \mathrm{~min}$ \\
\hline & Mass Detector & & Centroid \\
\hline & & Noise Level & $1.0 \times 10^{3}$ \\
\hline \multirow{4}{*}{$\begin{array}{l}\text { ADAP Chrom. } \\
\text { Build }\end{array}$} & Min. group size in \# of scans & & 15 \\
\hline & Group intensity threshold & & $1.0 \times 10^{3}$ \\
\hline & Min. highest intensity & & $1.0 \times 10^{3}$ \\
\hline & $m / z$ tolerance & & $0.01 \mathrm{~m} / \mathrm{z}$ \\
\hline \multirow[t]{7}{*}{ Chrom. deconv. } & Wavelets (ADAP) & $\mathrm{S} / \mathrm{N}$ threshold & 7 \\
\hline & & $\mathrm{S} / \mathrm{N}$ estimator & Intensity window $\mathrm{SN}$ \\
\hline & & Min feature height & 1 \\
\hline & & Coef./area threshold & 30 \\
\hline & & Peak duration & 1.00 \\
\hline & & RT wavelet range & 0.15 \\
\hline & $m / z$ center calculation & Median & \\
\hline \multirow[t]{3}{*}{ Spec. Deconv. } & Multivariate Curve Resolution & Deconvolution window width (min) & 0.15 \\
\hline & & Retention time tolerance (min) & 0.02 \\
\hline & & Minimum number of peaks & 1 \\
\hline \multirow[t]{6}{*}{ ADAP Aligner } & Min confidence ( 0 to 1 ) & & 0.05 \\
\hline & Retention time tolerance & & $0.1(\min )$ \\
\hline & $m / z$ tolerance & & $0.1(m / z)$ \\
\hline & Score threshold (0 to 1 ) & & 0.75 \\
\hline & Score weight ( 0 to 1$)$ & & 0.1 \\
\hline & Retention time similarity & Cross-correlation & \\
\hline \multirow[t]{4}{*}{ Gap filling } & Peak finder multithreaded & & \\
\hline & & Intensity tolerance & $0.1 \%$ \\
\hline & & $m / z$ tolerance & $0.2 \mathrm{~m} / \mathrm{z}$ \\
\hline & & retention time tolerance & $0.1 \mathrm{~min}$ \\
\hline
\end{tabular}

The files were submitted for processing by the spectral networks algorithm (GNPS) in three files: mgf file of the EI spectra deconvoluted by Mzmine 2, a quantification table of the peaks generated by Mzmine 2 and a metadata table, with information on the samples, such as LC $_{50}$, taxonomy, coding, etc. In GNPS, the data were adjusted as follows: fragment ion mass tolerance of $0.5 \mathrm{Da}$; min matched peaks of 5; score threshold of 0.5 . The advanced search options were: library class bronze; top history per spectrum of 1 and NIST and GNPS spectral libraries. In advanced network options: min pair cos 0.6 and network topK 10 . For more details of the network on the GNPS, access: https:/ /gnps.ucsd.edu/ProteoSAFe/ status.jsp?task=e980401aaf22484f83adead45f6012dc, accessed on 30 November 2021. 
Network visualization was performed in Cytoscape v.3.4.3. Node colors and sizes were mapped based on the metadata files, and the edge thickness attribute set to reflect cosine similarity scores, with thicker lines indicating greater similarity $[65,66]$.

Supplementary Materials: The following supporting information can be downloaded, Figures S1-S5 represent GC-EI/MS chromatograms of commercial essential oils tested for larvicidal activity against Ae. aegypti larvae. Essential oils: Juniperus communis (Cupressaceae); Origanum majorana (Lamiaceae); Cymbopogon martini (Poaceae); Boswellia carteri (Burseraceae); Mentha piperita (Lamiaceae); Citrus aurantium var. amara (Rutaceae); Eucalyptus citriodora (Myrtaceae); Eucalyptus globulus (Myrtaceae); Lavandula angustifolia (Lamiaceae); Lavandula hybrida (Lamiaceae); Cymbopogon flexuosus (Poaceae); Cymbopogon nardus (Poaceae); Cedrus atlantica (Pinaceae); Rosmarinus officinalis (Lamiaceae); Citrus aurantium subsp. Bergamia (Rutaceae); Perlagonium graveolens (Geraniaceae); Litsea cubeba (Lauraceae); Salvia sclareia (Lamiaceae); Amyris balsamifera (Rutaceae) and Eucalyptus staigeriana (Myrtaceae).

Author Contributions: Conceptualization, A.C.P., M.D.G., M.R.S.S. and N.P.L.; methodology, A.C.P., R.R.S. and M.R.S.S.; formal analysis, M.R.S.S. and L.C.A.; investigation, A.C.P. and M.D.G.; resources, L.S.E.; writing —original draft preparation, A.C.P.; writing—review and editing, A.C.P., M.R.S.S., P.C.V., J.L.C.L., N.P.L. and L.S.E. All authors have read and agreed to the published version of the manuscript.

Funding: This research was funded by the Brazilian Ministry of Health under Project ArboControl process no. TED 74/2016 and TED 42/2017. Additionally, to the following grants: process no.: 807/2020 (A.C.P), 142/2018 (M.D.G.) and 270/2017 (M.R.R.S) and FAPESP Thematic Project 2020/02207-5. The authors also acknowledge the Conselho Nacional de Desenvolvimento Científico e Tecnológico (CNPq); Coordenação de Aperfeiçoamento de Pessoal de Nível Superior (CAPES; finance code 001) and The Research Network Natural Products against Neglected Diseases (ResNet NPND).

Institutional Review Board Statement: Not applicable.

Informed Consent Statement: Not applicable.

Data Availability Statement: Not applicable.

Conflicts of Interest: The authors declare no conflict of interest.

\section{References}

1. Bhatt, S.; Gething, P.W.; Brady, O.J.; Messina, J.P.; Farlow, A.W.; Moyes, C.L.; Drake, J.M.; Brownstein, J.S.; Hoen, A.G.; Sankoh, O.; et al. The global distribution and burden of dengue. Nature 2013, 496, 504-507. [CrossRef] [PubMed]

2. Whitmire, R.E.; Burke, D.S.; Nisalak, A.; Harrison, B.A.; Watts, D.M. Effect of Temperature on the Vector Efficiency of Aedes aegypti for Dengue 2 Virus. Am. J. Trop. Med. Hyg. 1987, 36, 143-152. [CrossRef]

3. Duong, V.; Lambrechts, L.; Paul, R.E.; Ly, S.; Lay, R.S.; Long, K.C.; Huy, R.; Tarantola, A.; Scott, T.W.; Sakuntabhai, A.; et al. Asymptomatic humans transmit dengue virus to mosquitoes. Proc. Natl. Acad. Sci. USA 2015, 112, 14688-14693. [CrossRef]

4. Dai, D.N.; Chung, N.T.; Huong, L.T.; Hung, N.H.; Chau, D.T.M.; Yen, N.T.; Setzer, W.N. Chemical Compositions, Mosquito Larvicidal and Antimicrobial Activities of Essential Oils from Five Species of Cinnamomum Growing Wild in North Central Vietnam. Molecules 2020, 25, 1303. [CrossRef]

5. Nguyen, N.M.; Thi Hue Kien, D.; Tuan, T.V.; Quyen, N.T.H.; Tran, C.N.B.; Vo Thi, L.; Thi, D.L.; Nguyen, H.L.; Farrar, J.J.; Holmes, E.C.; et al. Host and viral features of human dengue cases shape the population of infected and infectious Aedes aegypti mosquitoes. Proc. Natl. Acad. Sci. USA 2013, 110, 9072-9077. [CrossRef] [PubMed]

6. Basurko, C.; Matheus, S.; Hildéral, H.; Everhard, S.; Restrepo, M.; Cuadro-Alvarez, E.; Lambert, V.; Boukhari, R.; Duvernois, J.-P.; Favre, A.; et al. Estimating the Risk of Vertical Transmission of Dengue: A Prospective Study. Am. J. Trop. Med. Hyg. 2018, 98, 1826-1832. [CrossRef]

7. Waggoner, J.J.; Gresh, L.; Vargas, M.J.; Ballesteros, G.; Tellez, Y.; Soda, K.J.; Sahoo, M.K.; Nuñez, A.; Balmaseda, A.; Harris, E.; et al. Viremia and Clinical Presentation in Nicaraguan Patients Infected With Zika Virus, Chikungunya Virus, and Dengue Virus. Clin. Infect. Dis. 2016, 63, 1584-1590. [CrossRef]

8. Silvério, M.R.S.; Espindola, L.S.; Lopes, N.P.; Vieira, P.C. Plant Natural Products for the Control of Aedes aegypti: The Main Vector of Important Arboviruses. Molecules 2020, 25, 3484. [CrossRef] [PubMed]

9. WHO. Available online: https://www.who.int/news-room/fact-sheets/detail/dengue-and-severe-dengue (accessed on 15 January 2022).

10. Zebitz, C.P.W. Effects of three different neem seed kernel extracts and azadirachtin on larvae of different mosquito species. J. Appl. Entomol. 1986, 102, 455-463. [CrossRef] 
11. Dua, V.K.; Pandey, A.C.; Raghavendra, K.; Gupta, A.; Sharma, T.; Dash, A.P. Larvicidal activity of neem oil (Azadirachta indica) formulation against mosquitoes. Malar. J. 2009, 8, 124. [CrossRef] [PubMed]

12. Pilon, A.C.; Valli, M.; Dametto, A.C.; Pinto, M.E.F.; Freire, R.T.; Castro-Gamboa, I.; Andricopulo, A.D.; Bolzani, V.S. NuBBE ${ }_{D B}$ : An updated database to uncover chemical and biological information from Brazilian biodiversity. Sci. Rep. 2017, 7, 7215. [CrossRef]

13. Park, H.-M.; Kim, J.; Chang, K.-S.; Kim, B.-S.; Yang, Y.-J.; Kim, G.-H.; Shin, S.-C.; Park, I.-K. Larvicidal Activity of Myrtaceae Essential Oils and Their Components Against Aedes aegypti, Acute Toxicity on Daphnia magna, and Aqueous Residue. J. Med. Entomol. 2011, 48, 405-410. [CrossRef] [PubMed]

14. Isman, M.B. Botanical Insecticides in the Twenty-First Century-Fulfilling Their Promise? Annu. Rev. Entomol. 2020, 65, 233-249. [CrossRef]

15. Isman, M.B. Bridging the gap: Moving botanical insecticides from the laboratory to the farm. Ind. Crops Prod. 2017, 110, 10-14 [CrossRef]

16. De Oliveira, J.L.; Campos, E.V.R.; Bakshi, M.; Abhilash, P.C.; Fraceto, L.F. Application of nanotechnology for the encapsulation of botanical insecticides for sustainable agriculture: Prospects and promises. Biotechnol. Adv. 2014, 32, 1550-1561. [CrossRef] [PubMed]

17. Sahayaraj, K. Nanotechnology and Plant Biopesticides: An Overview. In Advances in Plant Biopesticides; Springer: New Delhi, India, 2014; pp. 279-293.

18. Wolfender, J.L.; Marti, G.; Thomas, A.; Bertrand, S. Current approaches and challenges for the metabolite profiling of complex natural extracts. J. Chromatogr. A 2015, 1382, 136-164. [CrossRef] [PubMed]

19. Neto, F.C.; Pilon, A.C.; Selegato, D.M.; Freire, R.T.; Gu, H.; Raftery, D.; Lopes, N.P.; Castro-Gamboa, I. Dereplication of natural products using GC-TOF mass spectrometry: Improved metabolite identification by spectral deconvolution ratio analysis. Front. Mol. Biosci. 2016, 3, 59. [CrossRef]

20. Čajka, T.; Hajšlová, J. Gas chromatography-high-resolution time-of-flight mass spectrometry in pesticide residue analysis: Advantages and limitations. J. Chromatogr. A 2004, 1058, 251-261. [CrossRef] [PubMed]

21. Segers, K.; Declerck, S.; Mangelings, D.; Heyden, Y.V.; Van Eeckhaut, A. Analytical techniques for metabolomic studies: A review. Bioanalysis 2019, 11, 2297-2318. [CrossRef]

22. Bandeira, N.; Tsur, D.; Frank, A.; Pevzner, P.A. Protein identification by spectral networks analysis. Proc. Natl. Acad. Sci. USA 2007, 104, 6140-6145. [CrossRef]

23. Fox Ramos, A.E.; Alcover, C.; Evanno, L.; Maciuk, A.; Litaudon, M.; Duplais, C.; Bernadat, G.; Gallard, J.F.; Jullian, J.C.; Mouray, E.; et al. Revisiting Previously Investigated Plants: A Molecular Networking-Based Study of Geissospermum laeve. J. Nat. Prod. 2017, 80, 1007-1014. [CrossRef]

24. Aksenov, A.A.; Da Silva, R.; Knight, R.; Lopes, N.P.; Dorrestein, P.C. Global chemical analysis of biology by mass spectrometry Nat. Rev. Chem. 2017, 1, 54. [CrossRef]

25. Yang, J.Y.; Sanchez, L.M.; Rath, C.M.; Liu, X.; Boudreau, P.D.; Bruns, N.; Glukhov, E.; Wodtke, A.; De Felicio, R.; Fenner, A.; et al. Molecular networking as a dereplication strategy. J. Nat. Prod. 2013, 76, 1686-1699. [CrossRef] [PubMed]

26. Pluskal, T.; Castillo, S.; Villar-Briones, A.; Orešič, M. MZmine 2: Modular framework for processing, visualizing, and analyzing mass spectrometry-based molecular profile data. BMC Bioinform. 2010, 11, 395. [CrossRef] [PubMed]

27. Olivon, F.; Grelier, G.; Roussi, F.; Litaudon, M.; Touboul, D. MZmine 2 Data-Preprocessing to Enhance Molecular Networking Reliability. Anal. Chem. 2017, 89, 7836-7840. [CrossRef]

28. Röst, H.L.; Sachsenberg, T.; Aiche, S.; Bielow, C.; Weisser, H.; Aicheler, F.; Andreotti, S.; Ehrlich, H.-C.; Gutenbrunner, P.; Kenar, E.; et al. OpenMS: A flexible open-source software platform for mass spectrometry data analysis. Nat. Methods 2016, 13, 741-748. [CrossRef]

29. Tsugawa, H.; Cajka, T.; Kind, T.; Ma, Y.; Higgins, B.; Ikeda, K.; Kanazawa, M.; Vandergheynst, J.; Fiehn, O.; Arita, M. MS-DIAL: Data-independent MS/MS deconvolution for comprehensive metabolome analysis. Nat. Methods 2015, 12, 523-526. [CrossRef] [PubMed]

30. Shen, V.K.; Siderius, D.W.; Krekelberg, W.P.; Hatch, H.W. NIST Standard Reference Simulation Website. NIST Stand. Ref. Database Number 173. Available online: https:/ / doi.org/10.18434/T4M88Q (accessed on 15 November 2021).

31. Smith, C.A.; Maille, G.O.; Want, E.J.; Qin, C.; Trauger, S.A.; Brandon, T.R.; Custodio, D.E.; Abagyan, R.; Siuzdak, G. Metlin: A metabolite mass spectral database. Ther. Drug Monit. 2005, 27, 747-751. [CrossRef] [PubMed]

32. Horai, H.; Arita, M.; Kanaya, S.; Nihei, Y.; Ikeda, T.; Suwa, K.; Ojima, Y.; Tanaka, K.; Tanaka, S.; Aoshima, K.; et al. MassBank: A public repository for sharing mass spectral data for life sciences. J. Mass Spectrom. 2010, 45, 703-714. [CrossRef]

33. Hodgson, J. Mass spectrometry searches using MASST. Nat. Biotechnol. 2020, 38, 19-22. [CrossRef]

34. Nothias, L.F.; Petras, D.; Schmid, R.; Dührkop, K.; Rainer, J.; Sarvepalli, A.; Protsyuk, I.; Ernst, M.; Tsugawa, H.; Fleischauer, M.; et al. Feature-based molecular networking in the GNPS analysis environment. Nat. Methods 2020, 17, 905-908. [CrossRef] [PubMed]

35. Watrous, J.; Roach, P.; Alexandrov, T.; Heath, B.S.; Yang, J.Y.; Kersten, R.D.; Van Der Voort, M.; Pogliano, K.; Gross, H.; Raaijmakers, J.M.; et al. Mass spectral molecular networking of living microbial colonies. Proc. Natl. Acad. Sci. USA 2012, 109, 1743-1752. [CrossRef] [PubMed] 
36. Pilon, A.C.; Gu, H.; Raftery, D.; da Silva Bolzani, V.; Lopes, N.P.; Castro-Gamboa, I.; Carnevale Neto, F. Mass Spectral Similarity Networking and Gas-Phase Fragmentation Reactions in the Structural Analysis of Flavonoid Glycoconjugates. Anal. Chem. 2019, 91, 10413-10423. [CrossRef] [PubMed]

37. Chacon, D.S.; Torres, T.M.; da Silva, I.B.; de Araújo, T.F.; Roque, A.D.A.; Pinheiro, F.A.S.D.; Selegato, D.; Pilon, A.; Reginaldo, F.P.S.; da Costa, C.T.; et al. Erythrina velutina Willd. alkaloids: Piecing biosynthesis together from transcriptome analysis and metabolite profiling of seeds and leaves. J. Adv. Res. 2021, 34, 123-136. [CrossRef]

38. Pilon, A.C.; Vieira, N.C.; Amaral, J.G.; Monteiro, A.F.; Da Silva, R.R.; Spíndola, L.S.; Castro-Gamboa, I.; Lopes, N.P. Molecular networks: An analysis on annotations and discovery of new assets. Quim. Nova 2021, 44, 1168-1179. [CrossRef]

39. Conde-Martínez, N.; Bauermeister, A.; Pilon, A.; Lopes, N.; Tello, E. Integrating Molecular Network and Culture Media Variation to Explore the Production of Bioactive Metabolites by Vibrio diabolicus A1SM3. Mar. Drugs 2019, 17, 196. [CrossRef] [PubMed]

40. Fox Ramos, A.E.; Evanno, L.; Poupon, E.; Champy, P.; Beniddir, M.A. Natural products targeting strategies involving molecular networking: Different manners, one goal. Nat. Prod. Rep. 2019, 36, 960-980. [CrossRef] [PubMed]

41. Selegato, D.M.; Freire, R.T.; Pilon, A.C.; Biasetto, C.R.; de Oliveira, H.C.; de Abreu, L.M.; Araujo, A.R.; da Silva Bolzani, V.; Castro-Gamboa, I. Improvement of bioactive metabolite production in microbial cultures-A systems approach by OSMAC and deconvolution-based ${ }^{1}$ HNMR quantification. Magn. Reson. Chem. 2019, 57, 458-471. [CrossRef] [PubMed]

42. Neto, F.C.; Raftery, D. Expanding Urinary Metabolite Annotation through Integrated Mass Spectral Similarity Networking. Anal Chem. 2021, 93, 12001-12010. [CrossRef]

43. Demarque, D.P.; Espindola, L.S. Challenges, Advances and Opportunities in Exploring Natural Products to Control Arboviral Disease Vectors. Front. Chem. 2021, 9, 779049. [CrossRef] [PubMed]

44. Kim, H.W.; Wang, M.; Leber, C.A.; Nothias, L.-F.; Reher, R.; Kang, K.B.; van der Hooft, J.J.J.; Dorrestein, P.C.; Gerwick, W.H.; Cottrell, G.W. NPClassifier: A Deep Neural Network-Based Structural Classification Tool for Natural Products. J. Nat. Prod. 2021, 84, 2795-2807. [CrossRef] [PubMed]

45. Lubes, G.; Goodarzi, M. Analysis of Volatile Compounds by Advanced Analytical Techniques and Multivariate Chemometrics. Chem. Rev. 2017, 117, 6399-6422. [CrossRef] [PubMed]

46. Dyer, L.A.; Philbin, C.S.; Ochsenrider, K.M.; Richards, L.A.; Massad, T.J.; Smilanich, A.M.; Forister, M.L.; Parchman, T.L.; Galland, L.M.; Hurtado, P.J.; et al. Modern approaches to study plant-insect interactions in chemical ecology. Nat. Rev. Chem. 2018, 2, 50-64. [CrossRef]

47. Atanasov, A.G.; Zotchev, S.B.; Dirsch, V.M.; Orhan, I.E.; Banach, M.; Rollinger, J.M.; Barreca, D.; Weckwerth, W.; Bauer, R.; Bayer E.A.; et al. Natural products in drug discovery: Advances and opportunities. Nat. Rev. Drug Discov. 2021, 20, 200-216. [CrossRef] [PubMed]

48. Harvey, A.L.; Edrada-Ebel, R.; Quinn, R.J. The re-emergence of natural products for drug discovery in the genomics era. Nat. Rev. Drug Discov. 2015, 14, 111-129. [CrossRef] [PubMed]

49. Schirle, M.; Jenkins, J.L. Identifying compound efficacy targets in phenotypic drug discovery. Drug Discov. Today 2016, 21, 82-89. [CrossRef]

50. Gaudêncio, S.P.; Pereira, F. Dereplication: Racing to speed up the natural products discovery process. Nat. Prod. Rep. 2015, 32, 779-810. [CrossRef]

51. Neto, F.C.; Siquitelli, C.D.; Pilon, A.C.; Silva, D.H.S.; Bolzani, V.D.S.; Castro-Gamboa, I. Dereplication of phenolic derivatives of qualea grandiflora and qualea cordata (vochysiaceae) using liquid chromatography coupled with ESI-QToF-MS/MS. J. Braz. Chem. Soc. 2013, 24, 758-764. [CrossRef]

52. Aron, A.T.; Gentry, E.C.; McPhail, K.L.; Nothias, L.F.; Nothias-Esposito, M.; Bouslimani, A.; Petras, D.; Gauglitz, J.M.; Sikora, N.; Vargas, F.; et al. Reproducible molecular networking of untargeted mass spectrometry data using GNPS. Nat. Protoc. 2020, 15, 1954-1991. [CrossRef] [PubMed]

53. Yue, Y.; Zhang, Q.; Wang, J. Integrated Gas Chromatograph-Mass Spectrometry (GC/MS) and MS/MS-Based Molecular Networking Reveals the Analgesic and Anti-Inflammatory Phenotypes of the Sea Slater Ligia exotica. Mar. Drugs 2019, 17, 395. [CrossRef] [PubMed]

54. Olivon, F.; Apel, C.; Retailleau, P.; Allard, P.M.; Wolfender, J.L.; Touboul, D.; Roussi, F.; Litaudon, M.; Desrat, S. Searching for original natural products by molecular networking: Detection, isolation and total synthesis of chloroaustralasines. Org. Chem. Front. 2018, 5, 2171-2178. [CrossRef]

55. Kang, K.B.; Ernst, M.; van der Hooft, J.J.J.; da Silva, R.R.; Park, J.; Medema, M.H.; Sung, S.H.; Dorrestein, P.C. Comprehensive mass spectrometry-guided phenotyping of plant specialized metabolites reveals metabolic diversity in the cosmopolitan plant family Rhamnaceae. Plant J. 2019, 98, 1134-1144. [CrossRef] [PubMed]

56. Leão, T.; Wang, M.; Moss, N.; da Silva, R.; Sanders, J.; Nurk, S.; Gurevich, A.; Humphrey, G.; Reher, R.; Zhu, Q.; et al A Multi-Omics Characterization of the Natural Product Potential of Tropical Filamentous Marine Cyanobacteria. Mar. Drugs 2021, 19, 20. [CrossRef]

57. Nothias, L.F.; Nothias-Esposito, M.; Da Silva, R.; Wang, M.; Protsyuk, I.; Zhang, Z.; Sarvepalli, A.; Leyssen, P.; Touboul, D.; Costa, J.; et al. Bioactivity-Based Molecular Networking for the Discovery of Drug Leads in Natural Product Bioassay-Guided Fractionation. J. Nat. Prod. 2018, 81, 758-767. [CrossRef] 
58. Da Silva, R.R.; Wang, M.; Nothias, L.F.; van der Hooft, J.J.J.; Caraballo-Rodríguez, A.M.; Fox, E.; Balunas, M.J.; Klassen, J.L.; Lopes, N.P.; Dorrestein, P.C. Propagating annotations of molecular networks using in silico fragmentation. PLoS Comput. Biol. 2018, 14, e1006089. [CrossRef]

59. Naman, C.B.; Rattan, R.; Nikoulina, S.E.; Lee, J.; Miller, B.W.; Moss, N.A.; Armstrong, L.; Boudreau, P.D.; Debonsi, H.M.; Valeriote, F.A.; et al. Integrating Molecular Networking and Biological Assays To Target the Isolation of a Cytotoxic Cyclic Octapeptide, Samoamide A, from an American Samoan Marine Cyanobacterium. J. Nat. Prod. 2017, 80, 625-633. [CrossRef] [PubMed]

60. Aksenov, A.A.; Laponogov, I.; Zhang, Z.; Doran, S.L.F.; Belluomo, I.; Veselkov, D.; Bittremieux, W.; Nothias, L.F.; Nothias-Esposito, M.; Maloney, K.; et al. Autodeconvolution and molecular networking og gas chromatography-mass spectrometry data. Nat. Biotechnol. 2021, 39, 169-173. [CrossRef]

61. Jing, L.; Lei, Z.; Zhang, G.; Pilon, A.C.; Huhman, D.V.; Xie, R.; Xi, W.; Zhou, Z.; Sumner, L.W. Metabolite profiles of essential oils in citrus peels and their taxonomic implications. Metabolomics 2015, 11, 952-963. [CrossRef]

62. WHO. Guidelines for Laboratory and Field Testing of Mosquitos Larvicides; WHO: Geneva, Switzerland, 2005. Available online: https:/ / apps.who.int/iris/handle/10665/69101 (accessed on 15 November 2021).

63. Silva, R.L.; Demarque, D.P.; Dusi, R.G.; Sousa, J.P.B.; Albernaz, L.C.; Espindola, L.S. Residual Larvicidal Activity of Quinones against Aedes aegypti. Molecules 2020, 25, 3978. [CrossRef]

64. Wang, M.; Carver, J.J.; Phelan, V.V.; Sanchez, L.M.; Garg, N.; Peng, Y.; Nguyen, D.D.; Watrous, J.; Kapono, C.A.; Luzzatto-Knaan, T.; et al. Sharing and community curation of mass spectrometry data with Global Natural Products Social Molecular Networking. Nat. Biotechnol. 2016, 34, 828-837. [CrossRef]

65. De Oliveira, G.; Carnevale Neto, F.; Demarque, D.; de Sousa Pereira-Junior, J.; Sampaio Peixoto Filho, R.; de Melo, S.; da Silva Almeida, J.; Lopes, J.; Lopes, N. Dereplication of Flavonoid Glycoconjugates from Adenocalymma imperatoris-maximilianii by Untargeted Tandem Mass Spectrometry-Based Molecular Networking. Planta Med. 2016, 83, 636-646. [CrossRef] [PubMed]

66. Shannon, P.; Markiel, A.; Ozier, O.; Baliga, N.S.; Wang, J.T.; Ramage, D.; Amin, N.; Schwikowski, B.; Ideker, T. Cytoscape: A Software Environment for Integrated Models of Biomolecular Interaction Networks. Genome Res. 2003, 13, $2498-2504$. [CrossRef] [PubMed] 